\title{
EFFECT OF MASONRY INFILL WALLS ON THE NATURAL PERIOD OF REINFORCED CONCRETE BUILDINGS
}

\section{Waleed Abo El-Wafa Mohamed}

Lecturer, Civil Engineering Department, Faculty of Engineering, Assiut University, Assiut, Egypt.

(Received January 19, 2009 Accepted February 5, 2009)

\begin{abstract}
Although the reinforced concrete frame-infill systems are used throughout the world, they are rarely included in the numerical analysis of the structures. In this study, the effect of the infill walls on the natural period is investigated. Equivalent strut methodology is used to model the behavior of infill walls taking into consideration the effect of openings. A six floors reinforced concrete moment resisting frame building is modeled. Several configurations of infill walls are studied considering the wall openings. Natural vibration analysis is carried out for the studied building over a wide range of infill wall stiffness. The study is extended to investigate the interaction between the masonry infill walls and the R.C shear walls in buildings with different heights represented by the number of stories which ranges between 6 and 20 floors. All the considered shear wall buildings have fixed story total shear wall lengths to height ratios in each orthogonal direction. Finally, this study is intended with investigating the parameters of the equations presented by famous different codes to calculate the period of the shear wall buildings in comparison with modal analysis. It is found that excluding the effect of infill walls from modal analysis yields an undesired high overestimation of natural period increases as the height of building decreases. There is an extreme unrealistic variation in the results of natural period obtained from the second alternative of 2003 ECOL while there is high correlation between the results of modal analysis of wall infilled buildings and some specified code equations.
\end{abstract}

KEYWORDS: infill walls, wall openings, modal analysis, seismic codes

\section{INTRODUCTION}

Reinforced concrete framed buildings with infill walls, that are intended to serve as internal partitions or external cladding, are usually analyzed and designed as bare frames, without considering the contributions of infills. Masonry panels are normally considered secondary structures or non-structural components. Clearly these "nonstructural" masonry infill may respond structurally, redistribute lateral shear unexpectedly and drastically alter seismic behavior of the infilled frames. The simplification of ignoring their presence may in many cases result in unsafe structures especially in those buildings designed with obsolete codes or even without taking into account any seismic specification [1] - [3]. The infill walls have a direct influence on 
structural characteristics such as stiffness and energy dissipation capacity, unless adequate gaps lead to complete separation of the infills and the surrounding RC frame exist. However, even when there is no complete contact between the infills and the frame, the former will not remain intact under lateral loading. This is due to their tendency to undergo deformations of a shear mode. As it is practical to add such walls after the RC frame has been constructed and allowed to harden, gaps are not generally present, and despite the absence of shear connectors, the infills interact with the surrounding beams and columns [4]. It is therefore appropriate herein to allow for the participation of such elements in global structural behavior. The omission of infill walls effect can be related to the absence of building code provisions, the lack of knowledge of the composite behavior of the frame and the infills and also due to the unwanted analytical complexities they introduce to the structure [5], [6].

The fundamental period is an important design parameter that plays a significant role in the computation of design base shear. The design codes provide approximate empirical expressions to estimate the fundamental period. Although the use of more accurate methods of mechanics is permitted in the codes, which is in fact the default option in many codes including the 2003 Egyptian Code of Loads [7]. It is specified that the value of natural period obtained by such methods must not be overestimated as this tends to underestimate the seismic forces. In the beginning of the seismic excitation the undamaged structure will have much higher stiffness than the considered (i.e. accepted in the model) one. This means, that the structure should withstand loading that is several times larger than the design loading to which it has been dimensioned. The overestimation of natural period may mainly be related to uncertainties associated with the participation of nonstructural elements whose effects may not have been considered in period determination and on the seismic response [8], [9].

The periods of some actual concrete buildings were recorded during past earthquakes in many places in the world and compared to the code equations, distinct difference between the results was reported [8], [10]. Moreover, a recently conducted field study revealed that buildings are often much stiffer than that predicted by the computer analysis of the skeletal frame due to the participation of infill brick walls [11]. Experimentally, the influence of the "non-structural" elements was established in an illustrative way during an in-situ test of two eight-story buildings. While the first building is completed, only the main structure of the second one is completed, for the first building (the stiffness is resulted from the interaction between the main structural system and the masonry infills) the fundamental period was $0.60 \mathrm{~s}$. This value was recorded as $0.95 \mathrm{~s}$ for the second building (the stiffness is obtained only by the main structural system).

Most semi-empirical building codes use a building period directly proportion to the magnitude of the force that should be sustained by buildings at a specific stress level and provide empirical formulas to determine the lower bound fundamental period in order to establish the proper design force level. However, such codes have not settled on a uniform method for determining the period, because the required design force level and characteristics of buildings constructed in each region are different. To determine the design base-shear for seismic design, the formulas for determining the period specified in the current 2003 ECOL are derived exactly as those of the Eurocode 
- 8 [13]. In this connection, some considerations of the 2003 ECOL need to be urgently discussed due to their decisive influence on the structural safety.

Despite the relatively large number of seismic reliability studies in the literature, few deal with infilled frames and there is still a lack in the knowledge of many aspects concerning this concept. The main purpose of this study is to analytically investigates the effect of infill walls with different configurations on the natural period of moment resisting and shear wall R. C structures. The infill masonry walls are idealized using the equivalent strut methodology taking into consideration the effect of openings. The analyzed building is a typical building with and without masonry infill walls. Different eight configurations of shear walls are studied. The interaction between masonry infills and R. C shear walls over different building heights is evaluated through analyzing the used building with different five heights represented by the number of stories ranging from six stories to twenty stories. The equations related to the natural period exist in many international codes are discussed. Special concern is applied to analytically investigate the validity of the equations presented by the 2003 ECOL to estimate the period of R.C buildings with shear walls in comparison with the corresponding equations of UBC 97 [14]. The results of modal analysis carried out on the investigated shear wall buildings with five different heights and have masonry infill walls are compared with the corresponding results obtained from some specified codes.

\section{MODELING OF INFILL WALLS AS DIAGONAL STRUTS}

Investigations to model the behavior of masonry infill walls, experimentally and analytically, have been conducted over the past decades. Different types of analytical macro-models, based on the physical understanding of the overall behavior of an infill panel, were developed to model the behavior of infilled frames. The single strut model is the most widely used of the available models, though this model is the simplest one, it is unable to capture the local effects occurring to the frame members, but, it is evidently the most suitable one for analysis of large structures. Thus, R. C frames with unreinforced masonry walls are modeled as equivalent braced frames (EBF) with infill walls replaced by "equivalent struts". The early versions of this equivalent strut model included a pin-jointed strut with its width taken as one-third the infill diagonal. Using the theory of beam on elastic foundation, a non-dimensional parameter was defined as the relative lateral stiffness of the infill. This method was further extended to predict the lateral stiffness and strength of multi-story infilled frames [1]. Another model for representing the brick infill panel by equivalent diagonal strut was proposed by Mainstone [15] and widely used by many researchers. For this model, the strut area, $A_{e}$, was given using the following expressions:

$$
\begin{gathered}
A_{e}=w_{e} t \\
w_{e}=0.175(\lambda H)^{-0.4} \sqrt{H^{2}+L^{2}} \\
\lambda=\sqrt[4]{\frac{E_{i} t \sin (2 \theta)}{4 E_{c} I_{c} H_{i}}}
\end{gathered}
$$

where 
$h$ and $l$ are the height and length of the frame panel, respectively, $E_{c}$ and $E_{i}$ are the elastic moduli of the column and of the infill panel, respectively, $t$ is the thickness of the infill panel, $\theta$ is the angle defining diagonal strut, $I_{c}$ is the moment of inertia of the column and $H_{i}$ is the height of the infill panel.

Although infill walls usually have oversized openings, recent research has focused mainly on the simple case of infill walls without openings, research of the infill wall with openings is still limited. Recently, Asteris [5] investigated the influence of the masonry infill panel opening in the reduction of the infilled frames stiffness by means of finite element technique. The values of the stiffness reduction factor relying on the percentage opening and the position of opening are presented in the form of diagrams. His study found that the effect of openings can be estimated by multiplying the value of $w_{e}$ in Eq. (2) of Mainstone [15] by the value of the reduction factor represented by Asteris [5]. A schematic diagram of modeling infill walls as equivalent strut is shown in Fig. 1.
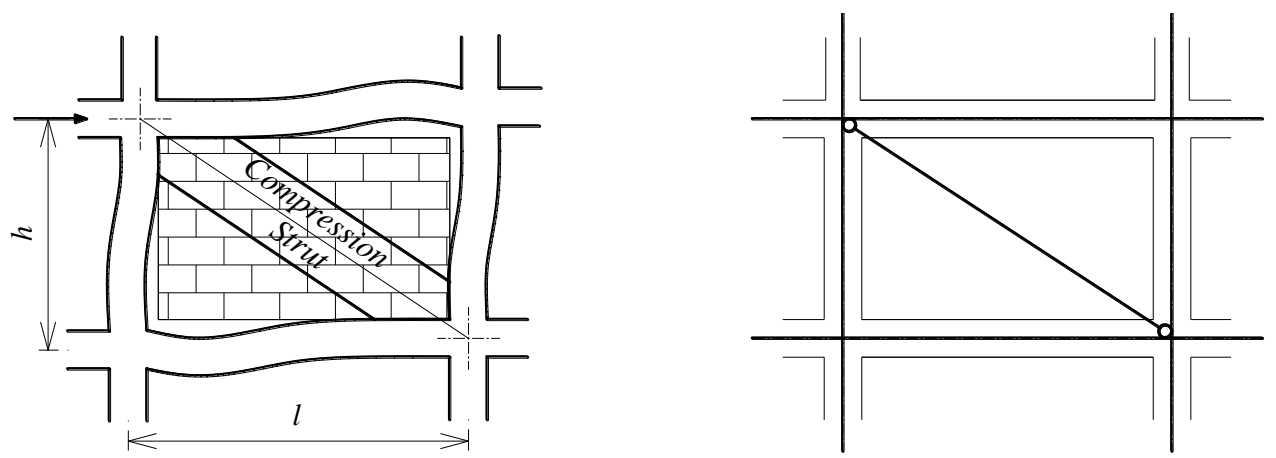

Fig. 1: Modeling of reinforced concrete frame with masonry infill

\section{DESCRIPTION OF MOMENT RESISTING FRAME BUILDING}

The first studied building is a typical moment resisting frame reinforced concrete building without shear walls. The dimensions of the building are 25.0 by $18.0 \mathrm{~m}$. The typical bay width is $5.0 \mathrm{~m}$ in the longitudinal direction and $6 \mathrm{~m}$ in the transverse direction, a plan of the building is shown in Fig. 2. The building has six floors with height above foundations of $19.5 \mathrm{~m}$, the typical story height is $3.0 \mathrm{~m}$, except the first story which has a height of about $4.0 \mathrm{~m}$, no basement is presented. The gravity load resisting system consists of $0.12 \mathrm{~m}$ thickness two way solid slabs supported by beams of $0.2 \mathrm{~m}$ width and overall depth of $0.6 \mathrm{~m}$, the beams are modeled with real reinforcement as specified by the design. The loads of each floor are transmitted to the columns which are modeled with different plan dimensions and reinforcement according to the design of building, the dimensions and reinforcement of the columns vary with height. The lateral load resisting system is the frame action between beams and columns, the dimensions of the columns in the first story are shown in Table 1. The compressive strength of concrete used for the building is 25.0 MPa while the used steel is high tensile with yield strength of $400 \mathrm{MPa}$. 
In this analysis, the infill walls function mainly as building cladding positioned at all four sides of building plus, in some specified configurations, internal partitions in some considered places. The different configurations of infill walls, considered in this study, mainly depend on two parameters. The first parameter is the number of cladding sides at which openings can be applied due to the site conditions, whether this side faces a street or adjacent to another building. The openings are applied to the considered external cladding walls only according to the applied considered configuration. The openings are applied with almost large size, each opening occupies about $18.5 \%$ of the wall at which it is applied. The second considered parameter of wall infills is the existence of internal walls. In this study the internal walls are applied only at some selected places, these internal walls are used as partitions without any openings. Relying on those two parameters, eight different configurations are considered to determine the effect of possible infill walls applications on the structural response. A plan of the different eight configurations of masonry infill walls used in this study along with the specified notation for each configuration are illustrated in Fig. 3, while the elevation of two sample walls along two orthogonal directions is shown in Fig. 4.

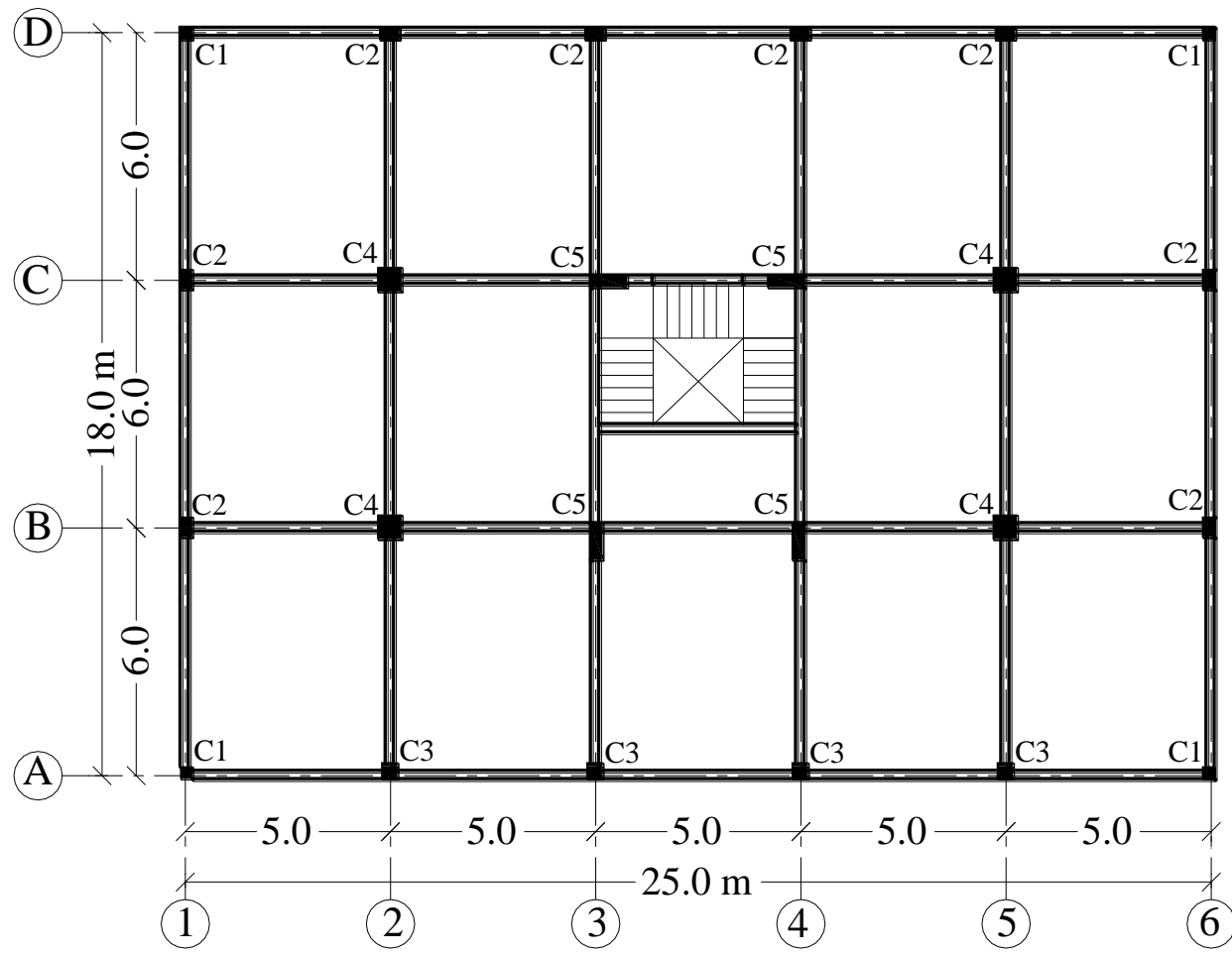

Fig. 2: Plan of the investigated building

Table 1: Dimensions of columns (m) in the first floor.

\begin{tabular}{|c|c|c|c|c|c|}
\hline Col. model & C1 & C2 & C3 & C4 & C5 \\
\hline \hline Dim. & $0.30 \times 0.30$ & $0.30 \times 0.50$ & $0.40 \times 0.40$ & $0.60 \times 0.60$ & $0.30 \times 0.90$ \\
\hline
\end{tabular}




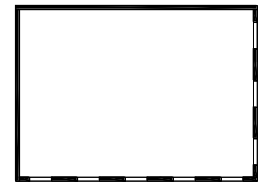

$2 \mathrm{~S}$

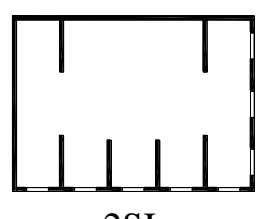

2SI

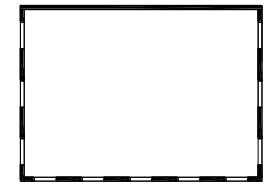

$3 \mathrm{~S}$

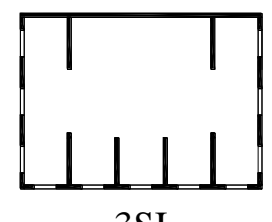

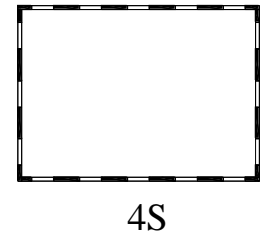

$4 \mathrm{~S}$

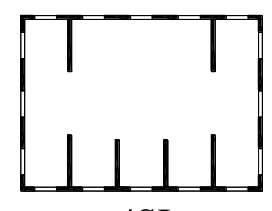

$4 \mathrm{SI}$

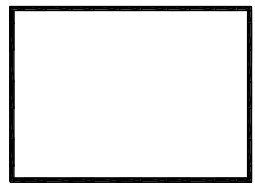

$4 \mathrm{SN}$

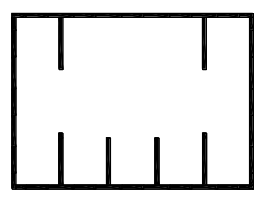

$4 \mathrm{SNI}$

Fig. 3: Different configurations of infill walls

The notations presented in Fig. 3 can be described as:

2S: Only 2 walls of the four external walls have openings, no internal walls.

3S: Three walls of the external walls have openings, no internal walls.

4S: All the four external walls have openings, no internal walls.

4SN: None of the external walls has openings, no internal walls.

2SI, 3SI, 4SI and 4SNI: The same external wall configurations as $2 \mathrm{~S}, 3 \mathrm{~S}, 4 \mathrm{~S}$ and $4 \mathrm{SN}$, respectively, but with the consideration of internal walls.

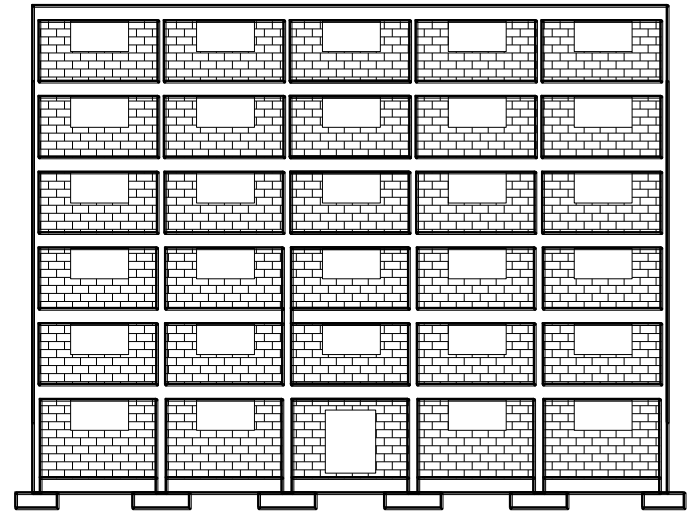

a) Longitudinal direction

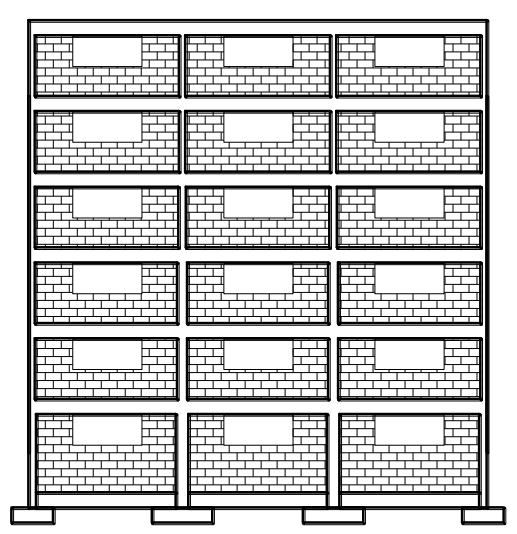

b) Transverse direction

Fig. 4: Elevation of sample external walls along two orthogonal axes

In the present study, the infill walls are idealized using equivalent diagonal strut model using Eq. (1) to Eq. (3). According to the charts presented by Asteris [5] and assuming the most critical position of walls, almost at the middle, the considered opening ratio of $18.5 \%$ results in a reduction factor of $40 \%$. So, the equivalent strut width resulted from Eqs. (2) and (3) of each considered wall is multiplied by this reduction factor. 
Different materials of masonry infill walls are considered through assigning different stiffness values of infills. The stiffness of infills takes 7 values ranges between $2.0 \mathrm{GPa}$ to $8.0 \mathrm{GPa}$. The three dimensional modal analysis is conducted using ETABS software package, nonlinear version 9 [16].

\section{4- MODAL ANALYSIS OF MOMENT RESISTING STRUCTURES}

The 3-D modal analysis of the studied building with different predescribed eight cases of infill wall configurations is carried out. For each case, two common different infill wall thicknesses which are $0.12 \mathrm{~m}$ and $0.20 \mathrm{~m}$ are considered. The modal analysis is carried out over masonry infill wall stiffness ranges between

2.0 GPa and 8.0 $\mathrm{GPa}$. The obtained results of the fundamental natural period are compared with those obtained from the 1993 Egyptian Code of Loads $(T=0.1 \mathrm{~N}$, where $N$ is the number of stories) [17] and the 2003 ECOL ( $T=0.075 H^{3 / 4}$ in which $\mathrm{H}$ is the total building height).

The effect of considering the masonry infill walls on the values of natural period can be observed clearly from Fig. 5 to Fig. 8. It is found that excluding the effect of these walls from the modal analysis can lead to highly overestimated natural period values. In comparison with code equations, the bare frame results in natural period values about twice the value suggested by the $1993 \mathrm{ECOL}$ and about 1.7 times that is suggested by the 2003 ECOL. This high overestimation can lead to high reduction in the seismic forces the structure is supposed to be designed to resist, and hence unsafe seismic design. The great problem of high variation between the natural vibration results obtained from modal analysis software, when ignoring the effect of infill walls, and the values suggested by the code equations almost faces researchers and designers. This high variation can be highly reduced by considering the effect of infill walls in the modal analysis. The reduction in the values of natural vibration of the building, considering the effect of infills, relative to the bare frame ranges between $25 \%$ and $67 \%$. Although the wide range of wall stiffness considered in this study, the results of natural period for all studied eight cases with infill walls are scattered around the suggested values of the 1993 ECOL and 2023 ECOL. For all the studied cases, the maximum upper difference related to these codes are about $49.5 \%$ and $29 \%$, respectively while the maximum lower difference related to the same codes are $-31.5 \%$ and $-41.0 \%$, respectively. The excess in the values of the maximum lower differences are resulted from the cases when ignoring the openings of the external walls. Frames with infill walls having stiffness ranges between 4.0 and $6.0 \mathrm{GPa}$, result in values of natural period with maximum difference related to the two preceding reference codes does not exceed $31.0 \%$ and $21.0 \%$, respectively, while maximum lower difference is about $-24.5 \%$ and $-35 \%$, respectively. The maximum upper and lower difference for all studied cases are shown in Tables $\mathbf{2}$ and $\mathbf{3}$.

The effect of changing the types of brick infills through changing their stiffness on the obtained results of fundamental period is studied. It is clear that the values of the fundamental period are reversely proportional to the masonry infill wall stiffness. The effect of stiffness on the obtained values of natural period is more remarkable with small stiffness values and decreases as the wall stiffness increases. The stiffness of the infill walls has almost the same effect on the different studied 
configurations. The difference between the maximum and minimum fundamental period, for each configuration, relative to that of the bare frame ranged between about $15.6 \%$ and $21.0 \%$.

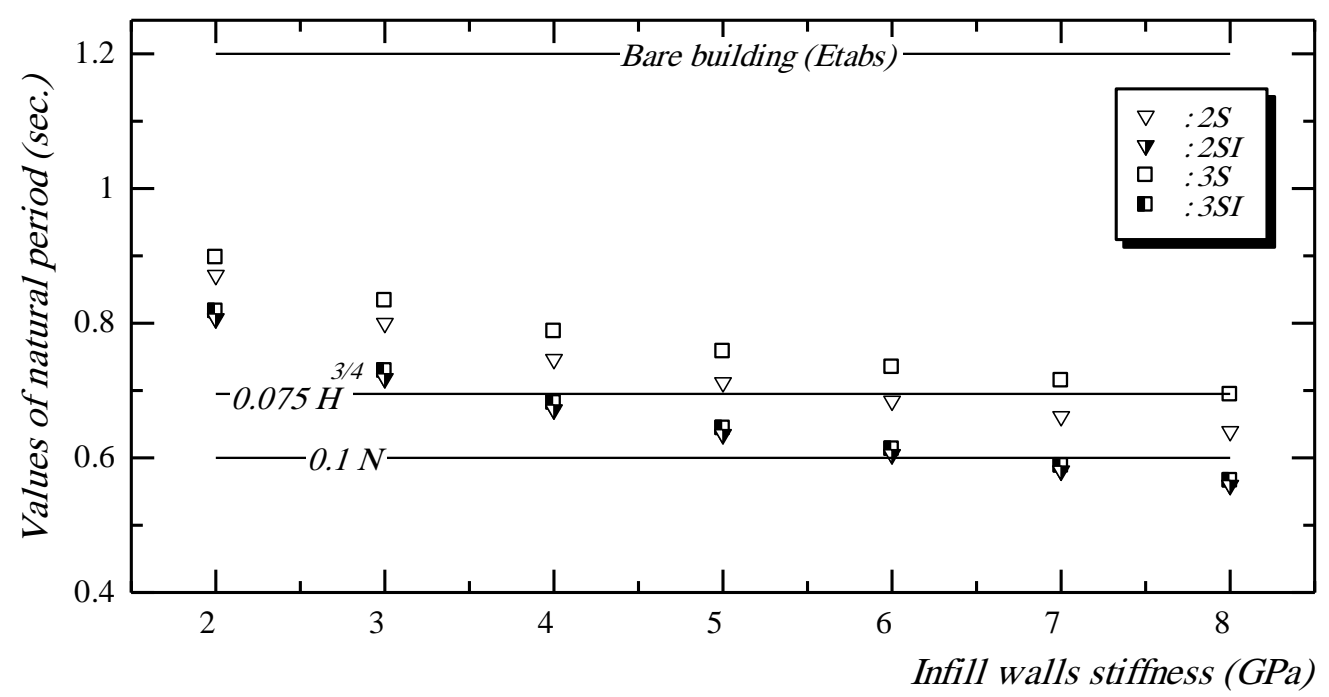

Fig. 5: Natural vibration of cases: $2 \mathrm{~S}, 2 \mathrm{SI}, 3 \mathrm{~S}$ and $3 \mathrm{SI}$ (wall thickness $=0.12 \mathrm{~m}$ )

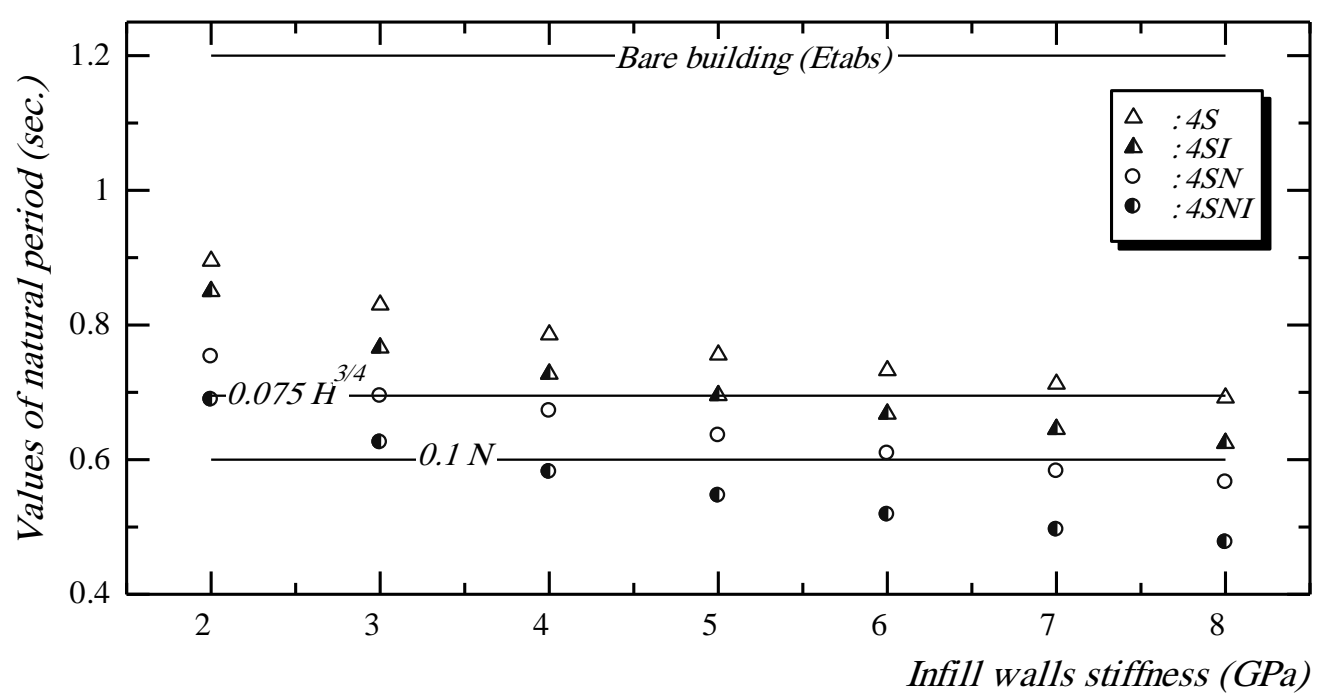

Fig. 6: Natural vibration of cases: 4S, 4SI, 4SN and 4SNI ( wall thickness $=0.12 \mathrm{~m}$ ) 


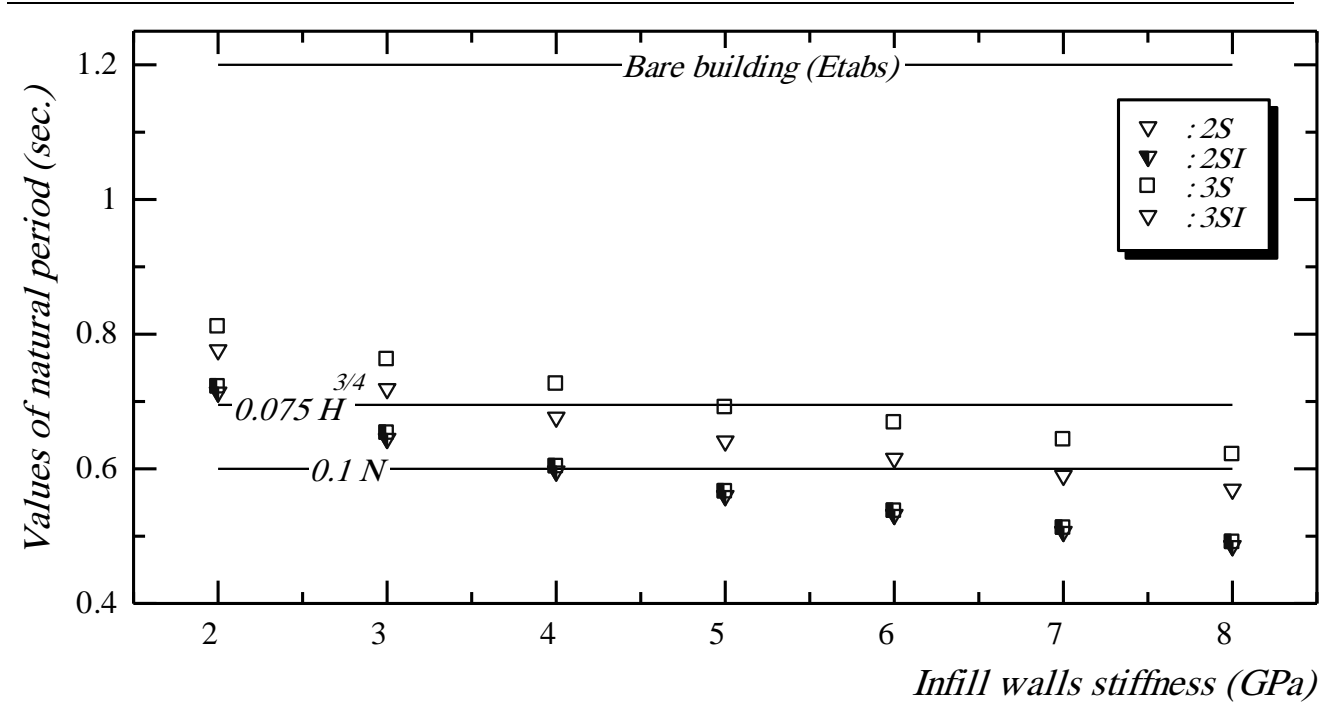

Fig. 7 : Natural vibration of cases: $2 \mathrm{~S}, 2 \mathrm{SI}, 3 \mathrm{~S}$ and $3 \mathrm{SI}$ (wall thickness $=0.2 \mathrm{~m}$ )

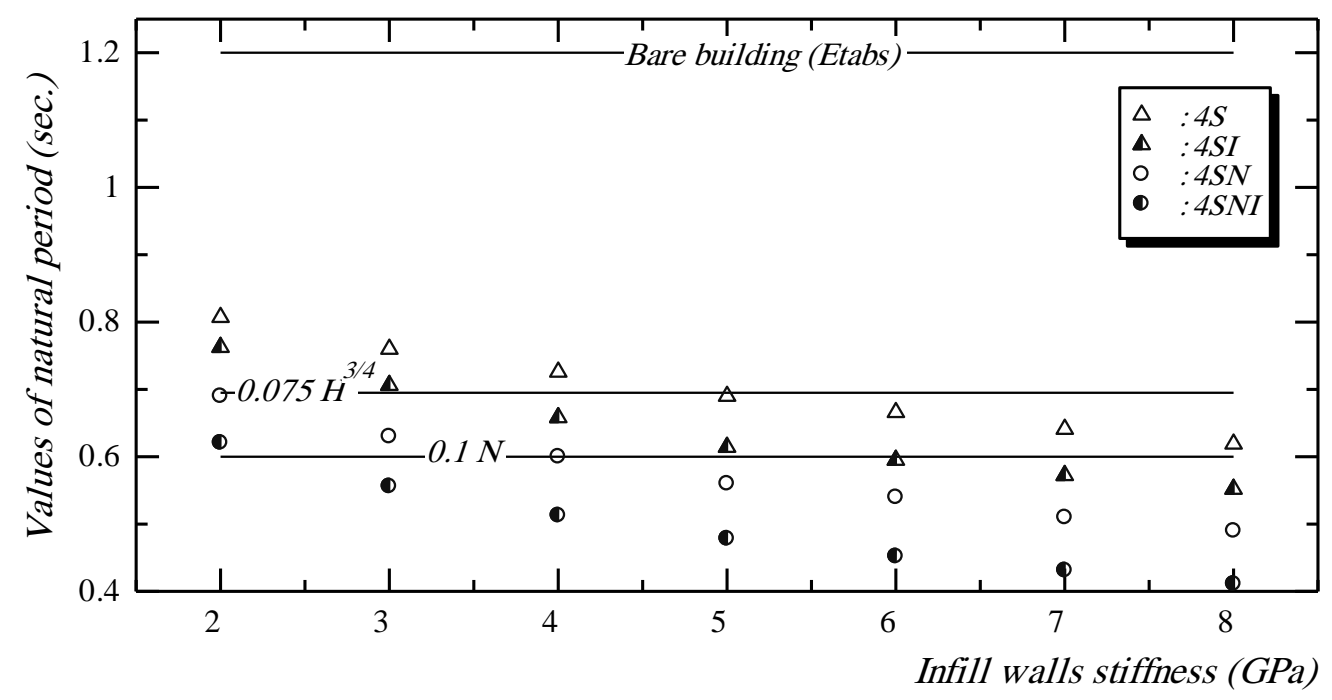

Fig. 8 : Natural vibration of cases: 4S, 4SI, 4SN and 4SNI (wall thickness $=0.20 \mathrm{~m}$ )

The results of the frames with infill wall thickness equal $0.12 \mathrm{~m}$ are compared to the same cases with wall thickness of $0.20 \mathrm{~m}$. It is realized that close results could be achieved using either thicknesses of walls at constant stiffness. The maximum increase in the values of natural period of frames with infill wall thickness $0.12 \mathrm{~m}$ relative to the same case with infill wall thickness 0.25 is about $15.6 \%$.

The influence of infill wall openings on the resulted natural period is studied. This effect can be clearly evaluated from studying the behavior of two configurations $4 \mathrm{~S}$ and $4 \mathrm{SI}$ in comparison with reference configurations $4 \mathrm{SN}$ and $4 \mathrm{SNI}$, respectively. It can be concluded that considering the openings in walls plays an important role in the resulted natural period, although in this study the openings are applied only at the 
external walls. The consideration of wall openings can result in a difference in the values of natural period, relative to the same case when ignoring the effect of openings up to $30 \%$ and $34 \%$ for frames with infill walls of $0.12 \mathrm{~m}$ and 0.20 wall thickness, respectively. The effect of number of walls which can have openings, due to the site considerations, is also studied. The variations of the number of external walls having openings from two walls to four walls can influence the resulted natural period up to about $14 \%$.

The effect of considering the internal walls on the results of modal analysis is also considered. It is found that including the internal walls, as specified in this study, in the model can decrease the values of natural period relative to same case ignoring the effect of internal walls with a ratio ranges between $5 \%$ and $26 \%$. It is noted that the effect of internal walls increases with increasing the stiffness of infill wall.

Table 2: Difference $(\%)$ between modal analysis (thickness $=0.12 \mathrm{~m}$ ) and codes.

\begin{tabular}{|l||l||l|l|l||l||l||l||l|l||}
\hline \multicolumn{2}{|c|}{ Case } & 2S & 2SI & 3S & 3SI & 4 S & 4SI & 4SN & 4SNI \\
\hline \hline 1993 & Upper & 45.2 & 34.5 & 49.6 & 36.3 & 49.2 & 28.8 & 25.5 & 8.4 \\
\cline { 2 - 9 } ECOL & Lower & 6.6 & -6.8 & 15.7 & -5.6 & 15.3 & -0.43 & -5.6 & -18.5 \\
\hline \hline $\begin{array}{l}2003 \\
\text { ECOL }\end{array}$ & Upper & 25.4 & 16.1 & 29.1 & 17.7 & 41.7 & 22.3 & 14.9 & -0.8 \\
\cline { 2 - 9 } & Lower & -8.0 & -19.5 & -0.1 & -18.5 & 4.1 & -10.1 & -20.4 & -31.3 \\
\hline
\end{tabular}

Table 3: Difference $(\%)$ between modal analysis (thickness $=0.2 \mathrm{~m})$ and codes.

\begin{tabular}{|l|l||l||l|l||l||l||l||l||l||}
\hline \multicolumn{2}{|c|}{ Case } & 2S & 2SI & 3S & 3SI & 4S & 4SI & 4SN & 4SNI \\
\hline \hline 1993 & Upper & 29.4 & 18.9 & 35.2 & 20.3 & 34.5 & 16.1 & 15.0 & -0.7 \\
\cline { 2 - 10 } ECOL & Lower & -5.1 & -19.1 & 3.6 & -18.0 & 3.2 & -10.9 & -18.3 & -29.5 \\
\hline \multirow{2}{2}{$\begin{array}{l}2003 \\
\text { ECOL }\end{array}$} & Upper & 11.7 & 2.7 & 16.7 & 3.9 & 27.1 & 9.7 & 3.5 & -10.7 \\
\cline { 2 - 10 } & Lower & -18.1 & -30.1 & -10.6 & -29.4 & -8.0 & -20.6 & -31.5 & -40.8 \\
\hline
\end{tabular}

\section{5- INTERACTION BETWEEN SHEAR AND INFILL WALLS}

This study is extended to evaluate the effect of the interaction between the reinforced concrete shear walls and masonry infill walls over different building heights. Doing so, the case of study building presented and analyzed in the previous sections is modified and redesigned to have 5 different heights represented by number of floors. Buildings with $6,9,12,16$ and 20 floors are studied. The lateral resisting system of all buildings consists, mainly, of shear walls plus moment resisting frames. The thickness of all shear walls are kept constant and equal $0.20 \mathrm{~m}$. The effective total lengths of shear walls in the first story in each orthogonal direction $\left(L_{w}\right)$ is designed to meet the seismic requirements and is taken as a ratio of the total height of building. This ratio $\left(L_{w} / H\right)$ is 0.20 for walls along the short direction and 0.165 for walls situated in the longitudinal direction. The position of shear walls for building with different heights represented by the number of floors are shown in Fig. 9.

For the purpose of brevity, only the results of $2 \mathrm{~S}$ and $2 \mathrm{SI}$ configurations are selected to represent the studied building having masonry infill walls with either 
$0.12 \mathrm{~m}$ or $0.20 \mathrm{~m}$ made of brick with stiffness equal 5.0 GPa. A total of 25 cases with infill masonry walls and 5 corresponding bare frame) are studied, number 12 or 20 is added to $2 \mathrm{~S}$ and 2 SI notations to mark for the thickness of infill walls.

The ratios between the natural period of the studied cases with infill walls obtained from modal analysis relative to the results obtained for the corresponding bare frames are represented in Fig. 10 and Table 4. It can be observed that generally, the effect of infill walls on the values of natural period increases as the height of building decreases. For six floors shear wall buildings, the period ratios relative to the bare frame for the different studied cases range between about $48.13 \%$ and $57.0 \%$ while for the 20 floor building these ratios highly increase to reach a range between $81.13 \%$ and $90.40 \%$. For each studied configuration this natural vibration ratio to bare frame increases as the building height increases.

The corresponding period ratios of the 6 floors buildings without shear walls are displayed in Fig. 10 as ( $\Delta$ ) for the purpose of comparison. It seems to be, for the considered building height, that infill walls have almost the same effect on the natural period whether the building is moment resisting frame or shear wall building, the difference in the results between the two cases does not exceed $4 \%$.

The existence of internal walls has slightly affected the period ratio of the studied cases, considering the internal infill walls in the model yields a difference in the results ranges between $8 \%$ and $12 \%$ for configurations with $0.12 \mathrm{~m}$ wall thickness and difference ranges between $6 \%$ to $15 \%$ for $0.25 \mathrm{~m}$ wall thickness configurations.

The thickness of walls has minor effect on the obtained period ratios of the different studied cases, also there effect is fading as the height of building increases. For 20 floors building, the thickness of walls affected the results by about $3.5 \%$ and $4.5 \%$ for building without and with internal walls, respectively. The maximum difference is recorded for building with minimum height, for this building the effect of wall thickness ranges between $7.5 \%$ and $9.3 \%$ for cases without and with internal walls, respectively.

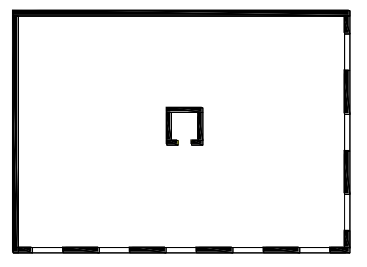

6 floors

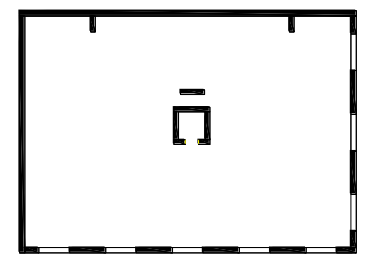

9 floors

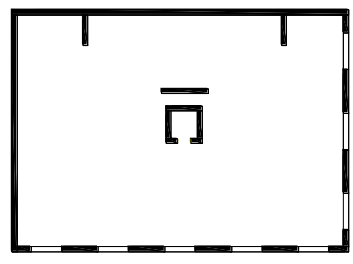

12 floors

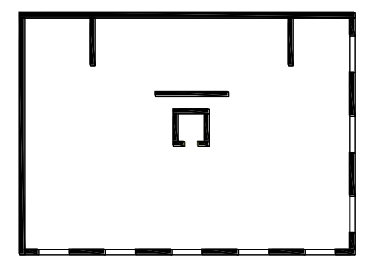

16 floors

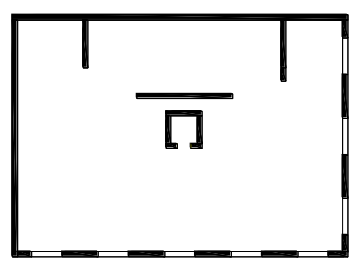

20 floors

Fig. 9: Positions of shear walls for buildings with different heights 


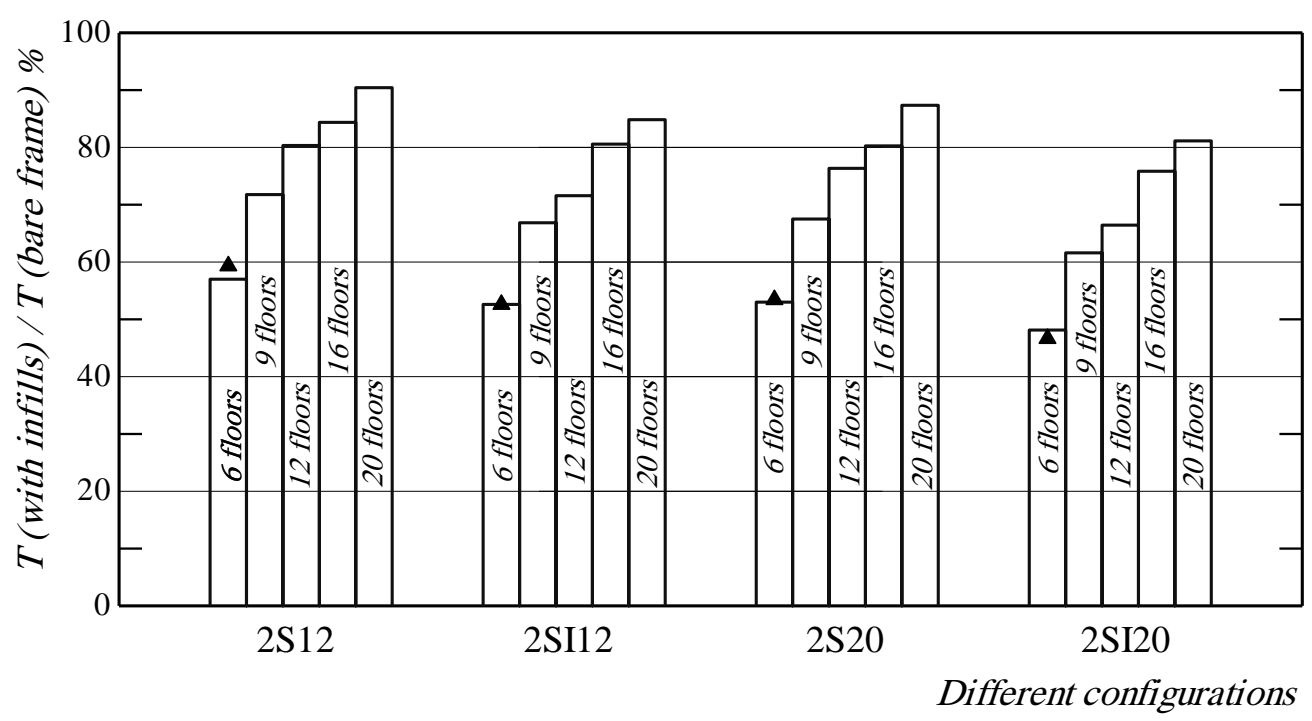

Fig. 10 : Ratios between period of buildings with infill walls to bare buildings

Table 4 : Period (\%) ratios of different configuration relative to the bare frame

\begin{tabular}{|c|c|c|c|c|c|}
\hline \multicolumn{2}{|r|}{ Case } & $2 \mathrm{~S} 12$ & 2 SI12 & $2 \mathrm{~S} 25$ & 2 SI25 \\
\hline \multirow{3}{*}{ 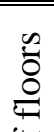 } & 6 floors & \multirow{2}{*}{\multicolumn{2}{|c|}{$\begin{array}{l}5 \% .0 \\
71.7\end{array}$ No. of stories }} & 53.00 & 48.13 \\
\hline & 9 floors & & & 67.51 & 61.6 \\
\hline & 12 floors & 80.33 & 71.57 & 76.35 & 66.44 \\
\hline \multirow{2}{*}{$\begin{array}{l}\dot{0} \\
\dot{z}\end{array}$} & 16 floors & 84.37 & 80.58 & 80.26 & 75.84 \\
\hline & 20 floors & 90.43 & 84.84 & 87.35 & 81.13 \\
\hline
\end{tabular}

\section{6- ANALYSIS AND COMPARISON WITH CODE EQUATIONS}

This section of the present study is concerned mainly with the provisions made related to the existence of masonry infill walls and equations presented by a variety of international codes to estimate the fundamental natural period of R. C shear wall structures. Deeply, the equations suggested by the 2003 ECOL to estimate the natural period of shear wall buildings are investigated in comparison with similar code equations. Finally, the results of natural period obtained for the different studied cases presented in section 5 are compared with 1993 ECOL, 2003 ECOL and UBC 97.

Very few design codes have made provisions on RC frames with infill walls, among which is the Eurocode -8 [13]. This code requires that "infill walls which contribute significantly to the lateral stiffness and resistance of the building should be taken into account. Eurocode - 8 considers brick masonry infilled R. C frames as dual systems which are classified into three ductility classes, namely, high, medium and low. The effect of infills is neglected for the low ductility classes. The Eurocode - 8 presents two alternatives for estimating the natural period for R. C shear wall buildings, the first is for buildings with height less than $80 \mathrm{~m}$. The value of $T$, can be estimated as: $T=C_{t} H^{3 / 4}$ 
in which, $C_{t}=0.05$

Alternatively, the value of $C_{t}$ for structures with concrete or masonry shear walls may be taken as:

$C_{t}=0.075 / \sqrt{A_{c}}$

with $A_{c}=\sum A_{i}\left(0.2+\left(L_{w i} / H\right)\right)^{2}$

in which;

$A_{c}$ is the combined effective area of shear walls in the first story.

$A_{i}$ is the effective cross sectional area of shear walls in the first story.

$L_{w i}$ is the length of shear wall $i$ in the first story.

The Eurocode - 8 modifies the seismic action effects using a new expression which is , $T_{a v e}$, the average value of the first mode period and can be obtained as:

$T_{\text {ave }}=\frac{T_{b f}+T_{i f}}{2}$

Where,

$T_{b f}=$ the fundamental period of the bare structure excluding the effect of infills.

$T_{i f}=$ fundamental period of bare structure considering infills as structural elements.

The UBC 97 considers the infill walls as nonstructural elements and neglects their effect on the natural vibration. For calculating the period of shear wall buildings, this code presented the same two alternatives, Eq. (4) for the first alternative and Eqs. (5) and (6) for the second alternative, as the Eurocode - 8 except that the second of Eq. (6) takes the form

$A_{c}=\sum A_{i}\left(0.2+\left(L_{w i} / H\right)^{2}\right)$

Noting that only the term $\left(L_{w i} / H\right)$ in Eq. (8) is squared whereas the whole $\left(0.2+\left(L_{w i} / H\right)\right)$ term in Eq. (6) is squared. If the period is determined using another method of analysis, the value of $T$ is limited. In Seismic Zone 4, the period cannot be over $30 \%$ greater than the value determined using code equatin and in zones 1,2 and 3 it cannot be more than $40 \%$ greater. This provision is included to eliminate the possibility of using an excessively long period to justify an unreasonably low base shear.

The Canadian Code [18] neglects the effect of infills, uses Eq. (4) but gives a condition that the natural period evaluated dynamically, should not exceed 1.5 the value of $T$ obtained using the empirical formulae in the code. The reason for this upper limit arises from the concern that the mathematical models, used in a dynamic analysis, frequently overestimate the periods e.g. by neglecting the non-structural elements.

The Indian Seismic Code [19] excludes the effect of brick infills and recommends that the fundamental period of an R.C building with infills be estimated using the empirical expression:

$T=\frac{0.09 H}{\sqrt{d}}$

where $d$ is the maximum base dimensions of the building along the considered direction of seismic force. 
The Egyptian Code of Loads (1993 ECOL) was first presented in 1993. This code provided a formula for calculating the fundamental natural period of shear wall buildings the same as Eq. (9). This equation lacks any details about the shear wall system such as the configuration, number and arrangement of shear walls. The 2003 ECOL, which was presented in 2003 and renewed in 2004, provides two alternatives for computing the fundamental period of buildings with shear walls. These two alternatives are exactly as the alternatives presented by the Eurocode - 8 through Eqs. (4) to (6). The 2003 ECOL limits the use of Eq. (4) to buildings other than moment resisting frames and with heights up to 60 meters. The second alternative is suggested for buildings with concrete or masonry shear walls, the only limitation of Eq. (6) is that the value of $\left(L_{w i} / H\right)$ not to exceed 0.9. The two alternatives do not present any provisions about infill walls or any limitations about the period that can be calculated using the method of dynamic analysis.

The second alternative of the 2003 ECOL is extensively investigated in comparison with the corresponding equations presented by the 1997 UBC. Eqs. (5), (6) and (8) depend on four variables, three of them are related to the shear walls themselves which are length, area and number of shear walls, the fourth variable is related to the height of building. A parametric study is carried out to investigate the influence of main variables affecting these two equations on the obtained values of the natural period. The considered parameters are the first story total effective shear wall lengths $\left(L_{w}\right)$ in one direction, number of shear walls in a considered direction, and the total height of building $(H)$. The first story effective total wall lengths in a considered direction is selected to be relative to the height of building $\left(L_{w} / H\right)$ and takes the ratios of $0.1,0.2,0.3$ and 0.4 , in the orthogonal direction the corresponding $\left(L_{w} / H\right)$ ratios are $0.825,0.165,0.25$ and 0.33 , respectively. The number of shear walls in a considered direction changes as 1,2,3 and 4 walls. The height of building, in turn, is considered to vary from $3.0 \mathrm{~m}$ up to $70 \mathrm{~m}$. A modal analytical study is carried out on the case study building, as bare frame excluding the effect of infills, using the new mentioned parameters of the total length and number of walls, the height of the building is represented by the number of floors which is taken as 6, 9, 12, 16 and 20 floors.

The influence of the effective total lengths of shear walls relative to the height of building $\left(L_{w} / H\right)$ on the obtained period using the investigated codes in comparison with the corresponding values of modal analysis, applying two shear walls in the considered direction, is shown in Fig. 11. In this figure the values obtained from the 2003 ECOL and UBC 97 are represented using thick continuous and dashed lines, respectively, while the results obtained from the modal analysis are given sympols. It is found that all the values suggested by the investigated two codes equations are, in contrary to the usual trend, higher than the values obtained from the modal analysis of the studied buildings, although ignoring the effect of infills. According to the 2003 ECOL, buildings with $\left(L_{w} / H\right)$ equal 0.1 yields extremely high values of natural period, at least about 3.4 times the values suggested by the same code for the same building without shear walls. Very high unrealistic values of fundamental period still also be obtained using $2003 \mathrm{ECOL}$ at $\left(L_{w} / H\right)$ ratio of 0.2 and ratio of 0.1 using UBC 97. It is also noted that the variation in the values obtained per any of the two codes as the shear wall lengths to height ratio changes is very high especially for the lower rations, this trend is more sound for 2003 ECOL than the UBC 97. Although this variation is similar in trend for the results of modal analysis, that the fundamental 
period is inversely proportional to the shear wall lengths, but is completely different in the values. Taking, for example, the results at building height equivalent to number of floors equal 12 floors it is found that the ratios of the degradation of the obtained natural period of building with $\left(L_{w} / H\right)$ ratios equal $0.1,0.2$ and 0.3 relative to the same building with ratio equal 0.4 is $3.2,1.9$ and 1.3, for 2003 ECOL, respectively. The corresponding obtained ratios for the UBC 97 are 2.2, 1.5 and 1.2, respectively. The variation in the results obtained from the modal analysis for the same ratios of wall lengths to height rations are much less than those obtained from the code equations, the degradation ratios, at the same height, are 1.4, 1.3 and 1.1 .

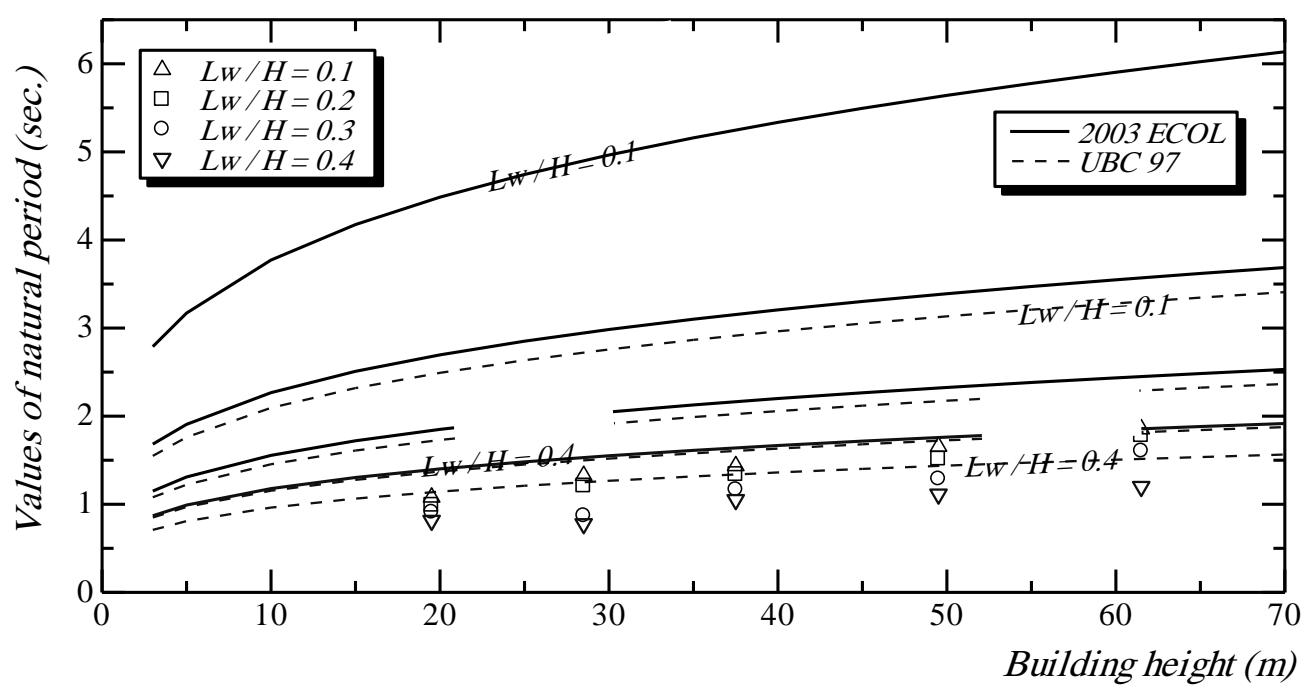

Fig. 11 : Effect of $\left(L_{w} / H\right)$ in the first story on the obtained natural period

The effect of changing the number of shear walls, in a considered direction, while keeping the ratio of total shear wall lengths in the first story to the building height fixed is also studied and presented in Fig. 12, same method of representation is used as Fig. 11. The number of shear walls, in the considered direction, is designed to be $1,2,3$ and 4 shear walls, for each case the ratio $\left(L_{w} / H\right)$ equals 0.2 . It is observed that there is extreme variation in the values obtained using the 2003 ECOL as the number of shear walls changes, although the $\left(L_{w} / H\right)$ ratio is kept fixed. This recorded variation is unlike the corresponding values obtained using the UBC 97 equation which, except the case of using one wall in a direction, exhibits very close results for the studied cases with different shear wall numbers of 2, 3 and 4 shear walls. Modal analysis is carried out for the case of study bare frame buildings with the previously mentioned heights, the same considered numbers of shear walls (2, 3 and 4) are considered for buildings with each studied height, in addition to these wall numbers, building with 6 and 9 stories are also studied using one shear wall in the considered direction. The modal analysis yields that there is some variation between the results of natural period due to changing the wall number but this variation is small and vanishes as the height of building increases. It is also noted from the modal analysis that the natural period is proportional to the number of shear walls, same outcome is observed 
for the two considered codes. To compare and evaluate the results obtained from 2003 ECOL, UBC 97 and the modal analysis, the results at height equivalent to building with 9 sttheories is considered. It is found that the variation in results due to changing the number of shear walls from 4,3 and 2 shear walls, relative to the results of buildings with shear walls equal 1 , is calculated to be 1.6, 1.5 and 1.3 for 2003 ECOL, respectively. The corresponding results obtained for all cases using the UBC 97 are about 1.1, while for the modal analysis this variation is $1.3,1.2$ and 1.1, respectively.

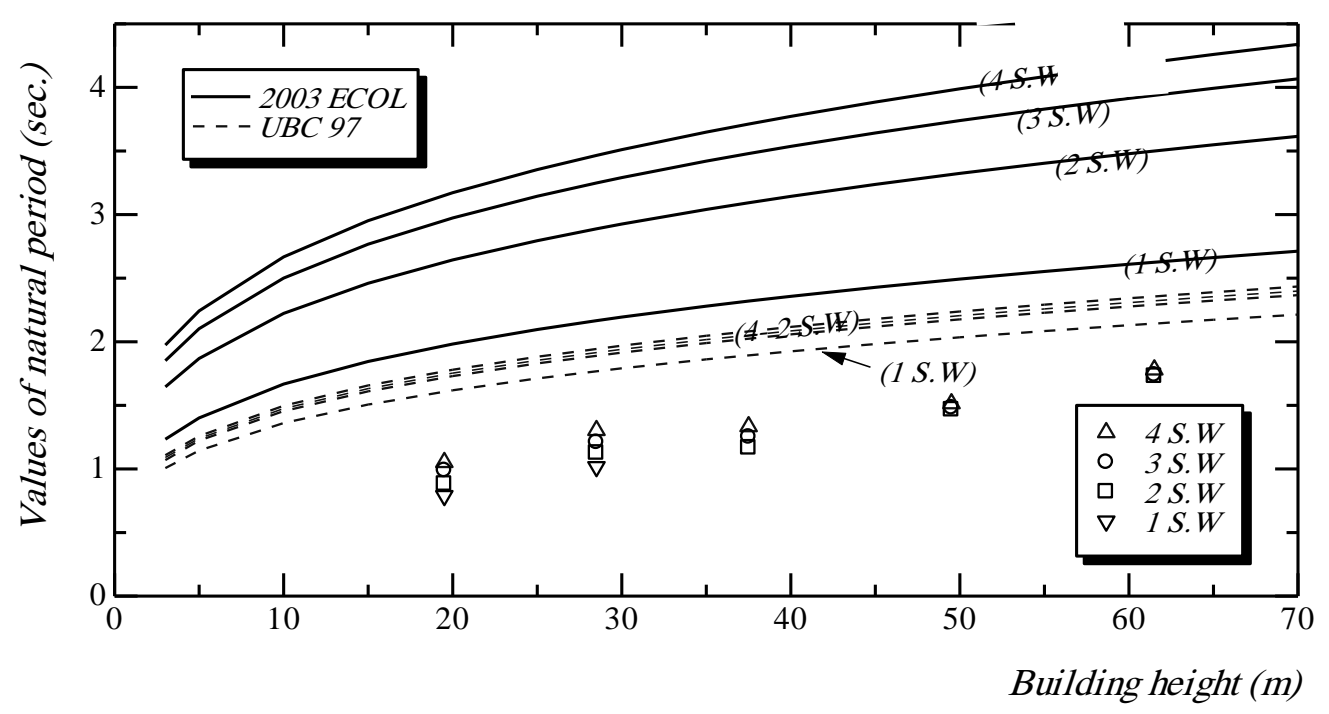

Fig. 12 : Effect of the number of shear walls in the first story on the obtained period

The high difference in the results, for the same condition, although there is high similarity between the equations used by the two codes, 2003 ECOL and UBC 97, worth to find an interpretation. The only difference between the two codes is that the second part in 2003 ECOL equation takes the shape $\left(0.2+\left(L_{w i} / H\right)\right)^{2}$ while this part takes the shape $\left(0.2+\left(L_{w i} / H\right)^{2}\right)$ in UBC 97 , as mentioned before. A fast investigation for this part of the equation used in 2003 ECOL and UBC 97, is carried ut. The values obtained from this part are plotted over individual values of $\left(L_{w i} / H\right)$ changing from 0.05 to 0.9 as shown in Fig. 13. It can be observed that the two codes will result in identical natural period for a value of $\left(L_{w i} / H\right)$ equal to 0.4 , values of $\left(L_{w i}\right.$ $/ H$ ) less than this value will result in natural period obtained from the $2003 \mathrm{ECOL}$ higher than the corresponding values obtained from the UBC 97 and vice versa, noting that $L_{w i}$ represents the length of an individual shear wall. It is clear from this figure that the 2003 ECOL is very sensitive for the lower values of $\left(L_{w i} / H\right)$, as an example, changing the value of $\left(L_{w i} / H\right)$ from 0.1 to 0.2 results in a change in the value obtained by the considered part of the equation of $2003 \mathrm{ECOL}$ from 0.09 to 0.16 while for the UBC 97 this change for the same ratios is only from 0.21 to 0.24 . 


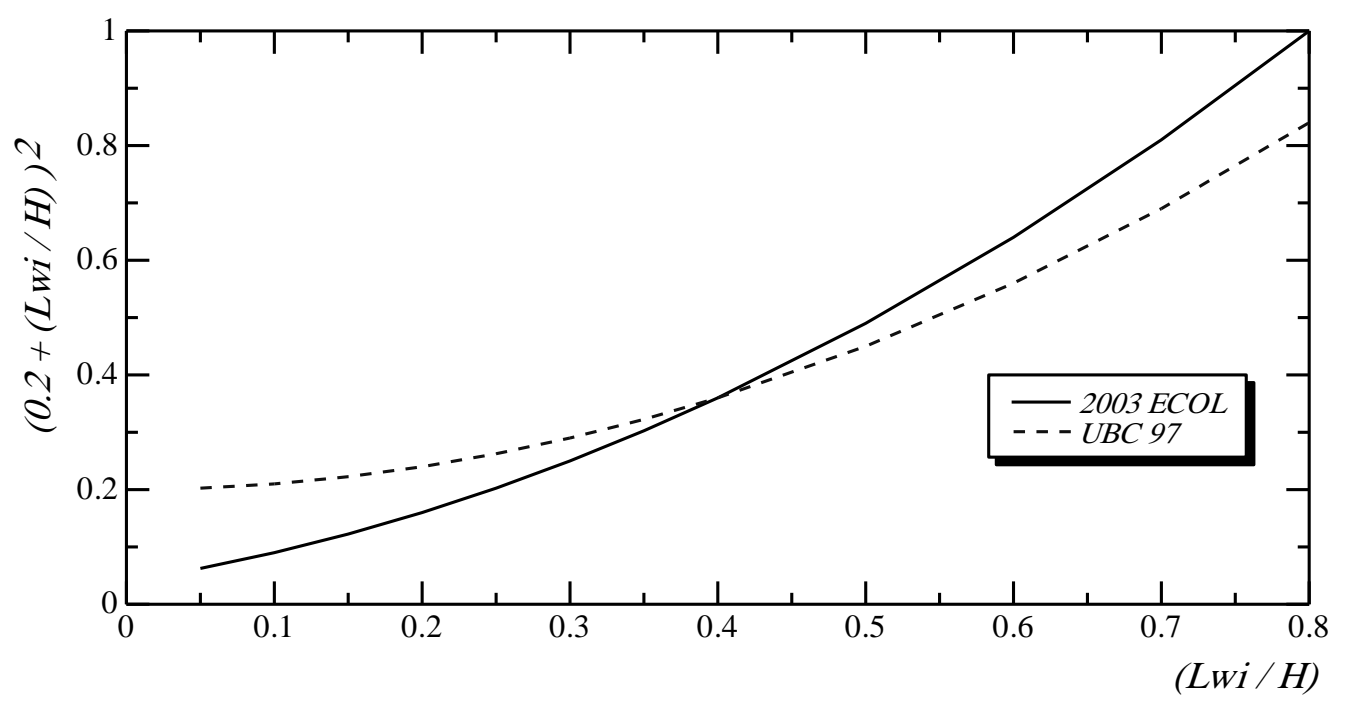

Fig. 13 : Interpretation of the difference between 2003 ECOL and UBC 97

Finally, the maximum and minimum values, corresponding to cases $2 \mathrm{~S} 12$ and 2SI20, of natural period obtained from the modal analysis for the case study buildings, presented in section 5 with infill walls along with the results of the corresponding bare frame buildings are compared to the values obtained from $1993 \mathrm{ECOl}, 2003 \mathrm{ECOL}$ and the UBC 97. The two alternatives of the 2003 ECOL and UBC 97 are used, noting that the first alternative is the same for these two codes. The studied cases have either 2 or 4 shear walls in the considered direction, so the second alternative of either $2003 \mathrm{ECOL}$ and UBC 97 code are presented with 2 and 4 walls. The results are shown in Fig. 14, it can be concluded that there is extreme difference between the results obtained using the two alternatives of the 2003 ECOL, the second alternative of the 2003 ECOL results in values of natural period about 3.6 to 6 times higher than the first alternative. The same trend is observed also for the UBC 97 but with less variation, the second alternative of this code gives values about 2.0 to 3.3 times the first alternative. It is also worth to mention here that, in contrary to what should be in seismic design, the second alternative of both considered codes gives values much higher than the values obtained from the modal analysis of the studied building even the bare frame building. The 1993 ECOL and the first alternative of the two considered codes give, some how, close results. It is very clear that the maximum and minimum values of fundamental period obtained from the modal analysis of the studied building with infills are very close from the values suggested by the $1993 \mathrm{ECOL}$ and the first alternative of the 2003 ECOL. The maximum difference between the results of modal analysis, relative to 1993 ECOL code equation, ranges between $3.3 \%$ and $34.0 \%$ for cases with infill walls, the bare frame exhibits high deviation from this equation ranges between $30.3 \%$ and $134.0 \%$. The corresponding comparison with the first alternative of the 2003 ECOL yields deviation in the values of natural period obtained for buildings with infills from about $0.6 \%$ to $35.6 \%$ and for the bare frame building the deviation is still very high and ranges between $54.9 \%$ and $108.6 \%$. 


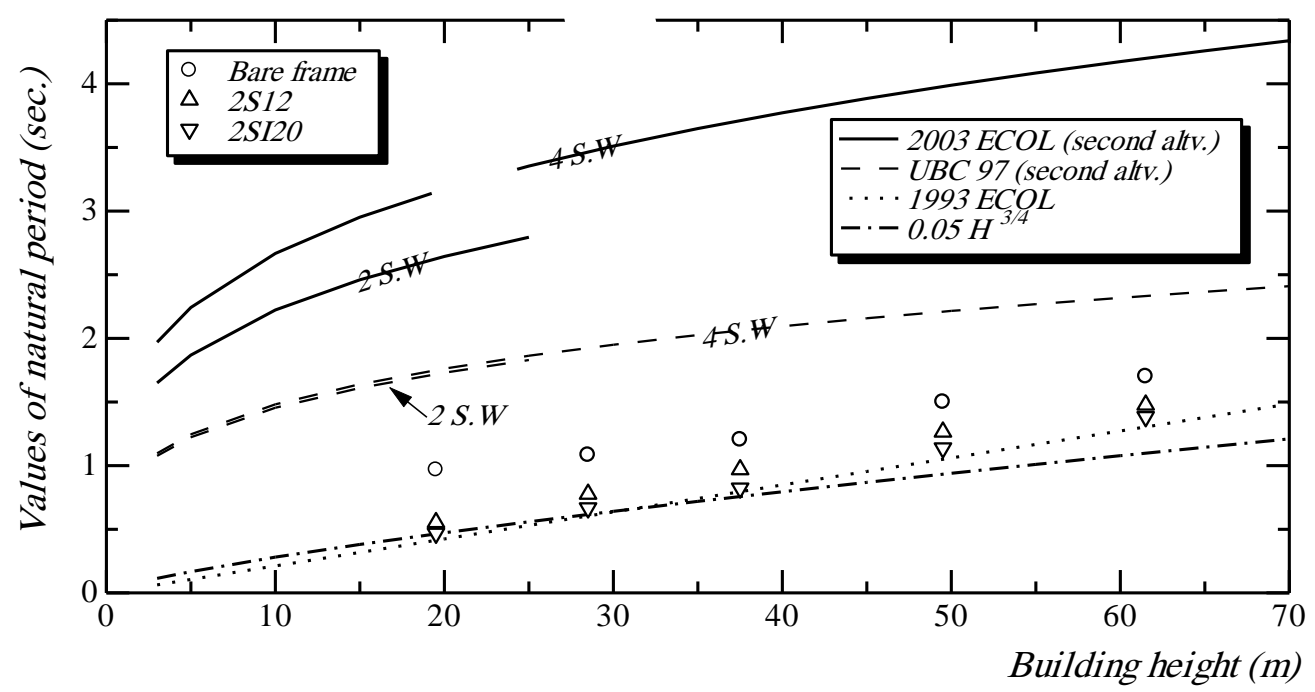

Fig. 14 : Comparison between modal analysis and the specified code equations

\section{CONCLUSIONS}

An analytical study is carried out to evaluate the effect of masonry infills with openings on the fundamental period of buildings. Variety of different infill thickness and configurations over a wide range of infill stiffness are considered. The interaction between ifill and shear walls over different heights of buildings represented by the number of floors which ranges between 6 and 20 floors is studied. Deep investigation of the 2003 ECOL equations for estimating period in comparison with corresponding codes is presented and followed by a comparison of the obtained modal analysis results with specified codes equations. The following conclusions may be drawn out.

1) Ignoring the effect of masonry infill walls from the modal analysis of moment resisting reinforced concrete frame buildings results in very high overestimation of the fundamental period in comparison to the values obtained from ECOL equations. This high overestimation will, in turn highly reduce the seismic forces the building should be designed to resist. Considering the effect of infills, especially with medium stiffness, in the modal analysis yields values of fundamental period very close to those suggested by the ECOL, either 1997 or 2003 editions.

2) The modal analysis of the studied moment resisting frame buildings proved that the consideration of the openings in the infill walls plays an important role in the obtained values of fundamental period. A change in the obtained results due to the consideration of openings could reach up to $34 \%$. Infill walls with either 0.12 or $0.2 \mathrm{~m}$ thickness results in relatively close behavior with maximum difference in the values of period does not exceed $15.4 \%$. Including the internal walls in the analysis resulted in a change of the obtained results ranged between $5 \%$ and $26 \%$.

3) The effect of infills on the shear wall buildings highly increases as the total height of building decreases. The existence of reinforced concrete shear walls in the building highly reduces the effect of changing the thickness of masonry infills 
or including the internal walls in the analysis rather than the moment resisting frame buildings.

4) Using the second alternative of the 2003 ECOL to determine the period of shear wall buildings yields extreme variation in the results due to changing either the ratio or even changing the number of shear walls in a considered direction. The results obtained from the 2003 ECOL are completely different from the corresponding UBC 97 equations or the results obtained from the modal analysis even with bare frame. The reason for the extreme deviation in the results of the 2003 ECOL is found to be related to that the $\left(\left(0.2+\left(L_{w i} / H\right)\right)^{2}\right.$ part of the 2003 ECOL equation is very sensitive for $\left(L_{w i} / H\right)$ values less than 0.3 and hence the number of shear walls associated with these ratios.

5) There is extreme difference between the results obtained using the two alternatives of the same code, either 2003 ECOL or UBC 97. The values of fundamental period obtained from the modal analysis of shear wall building with infills are very close from the values suggested by the 1993 ECOL or the first alternative of 2003 ECOL equations. There is high deviation of the results obtained from modal analysis of bare frame building and the last mentioned two codes equations.

\section{REFERENCES}

1- Kormaz, K.A., Demir, F., Sivri, M.: “ Earthquake Assessment of R/C Structures with Masonry Infill Walls " International Journal of Science \& Technology, Volume 2, No. 2, pp. 155-164, 2007.

2- Flanagan, R.D., Bennett, R.M.: “ In-plane Behavior of Structural Clay tile Infilled Frames" Journal of Structural Engineering, Vol. 125, No. 6, pp. 590-599, 1999.

3- Chiou, Y., Tzeng, J., Tzeng, Y.: " Experimental and Analytical Study of Masonary Infilled Frames" , Journal of Structural Engineering, Vol. 125, No. 10, pp. 1109-1117, 1999.

4- Dymiotis, C., Kappos, A., Chryssanthopoulos, K.: “ Seismic Reliability of Masonry - Infilled RC Structures ” Journal of Structural Engineering, Vol. 127, No. 3, pp. 296-305, 2001.

5- Asteris, P.G.: “ Lateral Stiffness of Brick Masonry Infilled Plane Frames " Journal of Structural Engineering, Vol. 129, No. 8, pp. 1071-1079, 2003.

6- Berman, J.W., Celik, O.C., Bruneau, M.: “ Comparing Hysteretic Behavior of Light-Gauge Steel Plate Shear Walls and Braced Frames " Journal of Structural Engineering, Vol. 125, No. 6, pp. 578-589. 1999.

7- " The Egyptian Code for Calculation of Loads and Forces in Structural and Building Work, ECL 201 " Housing and Building Research Center, Cairo, Egypt, 2003.

8- Tinawi, R.: "An Overview of Fifty Years of Development for the Canadian Seismic Building Code " EGYQUAKE 3, Third Egyptian Conference on Earthquake Engineering, Cairo, 2004.

9- Saatcioglu, M., Humar, J.: " Dynmic Analysis of Buildings for Earthquake Resistant Design " Research Press Web site at http://cjce.nrc.ca on 23 April 2003. 
10- “ NEHRP Recommended Provisions for Seismic Regulations for New Buildings and other Strurctures "Building Seismic Safety Council, Washington, D.C., 1997.

11-Balendra, T., Lam, N.T., Wilson, J.L., Kong, K.H.: " Analysis of Long-Distance Earthquake Tremors and Base Shear Demand for Buildings in Singapore " Journal of Engineering Structures, Vol. 24, pp. 99-108, 2002.

12- Dimova, S.L., Tzenov, L.L.: "On the Modeling of Structures in EUROCODE - 8" The Bulletin of the European Association for Earthquake Engineering, Volume 20, No. $1 / 2,2001$

13- Eurocode-8, "Design of Structures for Earthquake Resistance " The European Committee for Standardization, Final Draft, December 2003.

14- Uniform Building Code, " Structural Engineering Design Provisions " International Conference of Building Officials (ICBO), Volume 2, Whittier, California, USA, 1997.

15- Mainstone, R. J.: " Supplementary Note on the Stiffness and Strength of Infilled Frames.' Building Research Station, Garston, Watford, 1974.

16- " ETABS, Nonlinear version 9 Beta, Extended 3-D Analysis of Building Systems" Computers and Structures, Inc., Berkeley, U.S.A., 2005.

17- "The Egyptian Code for Calculation of Loads and Forces in Structural and Building Work " Housing and Building Research Center, Cairo, Egypt, 1997.

18- "National Building Code of Canada" National Research Council of Canada, Ottawa. 2005.

19- "Indian Standard Criteria for Earthquake Resistant Design of Structures " Part 1: General Provisions of Buildings, IS 1893 (Part 1) : 2002, Bureau of Indian Standards, New Delhi, 2002.

\section{تأثير حوائط البناء علي زمن الفترة الطبيعية الأساسية للمنشآت الخرسانية المسلحة}

علي الرغم من أن حوائط البناء تستخدم في معظم المباني الخرسانية كواجهات أو فواصل داخلية إلا أن

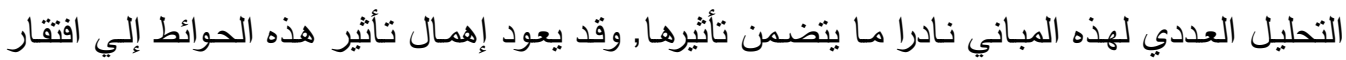

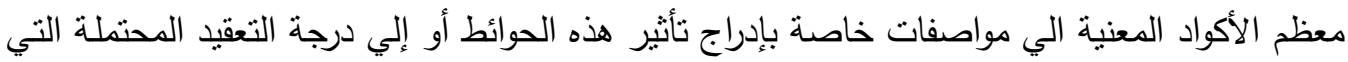

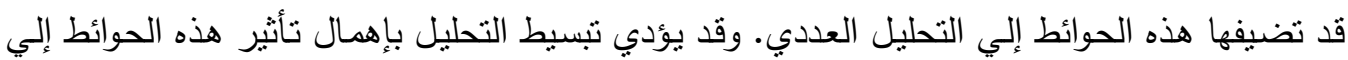

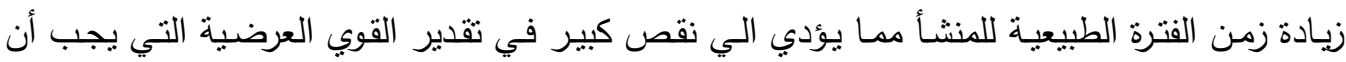
يصمم المبني لمقاومتها ومن ثم تصميم مباني قد لا تحتمل القوي العرضية التي يجب أن أنقائ تقاومها.

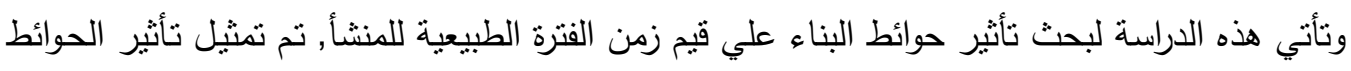

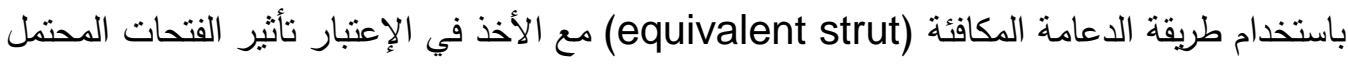

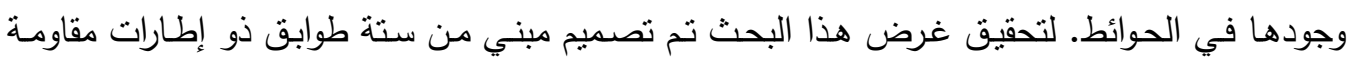

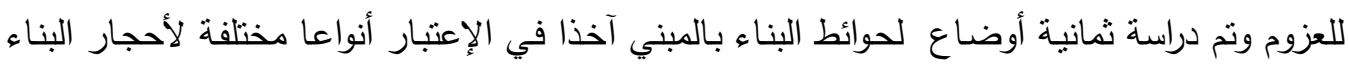

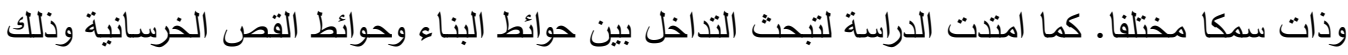


لمباني ذات ارتفاعات مختلفة تبدأ من ستة أدوار وحتي عشرين دورا. وفي هذه المباني تم تصميم حوائط

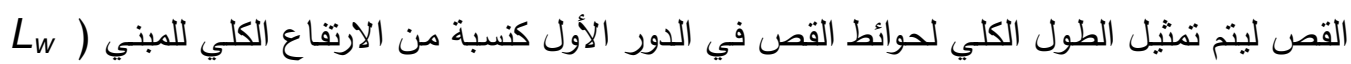
ECOL (I/H (1993, ECOL 2003 المعادلات ببعض الأكواد العالمية وكذلك بالنتائج التي تم الحصول عليها من التحليل الثكلي (anadal لمجموعة من المباني سواء بأخذ تأثثر حوائط البناء في الاعتبار أو بإهمال تأثثرها.

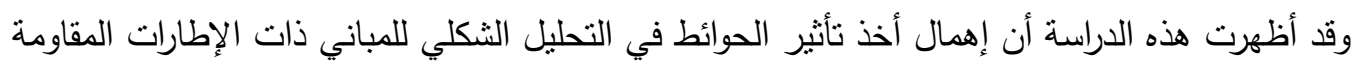

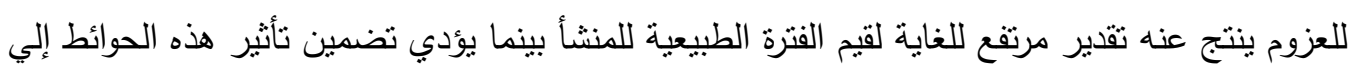

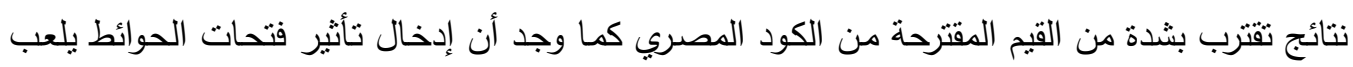

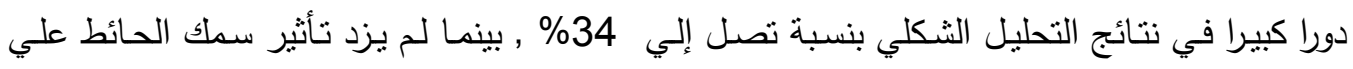

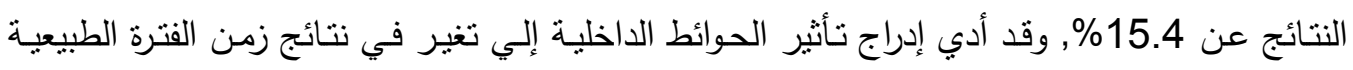

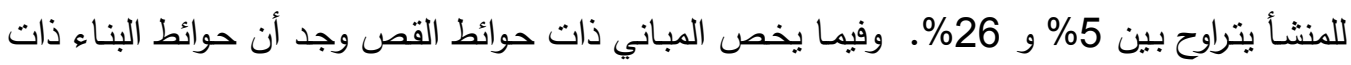

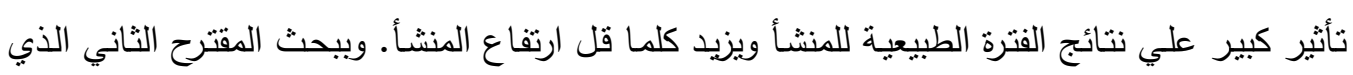

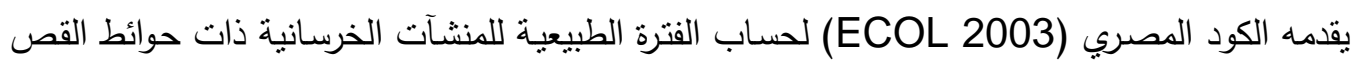

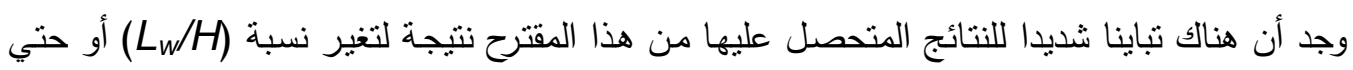
عدد حوائط القص كما أن هذه النتائج تختلف اختلافا جذريا عن نتائج التحليل الثكلي وكذللك النتائج المتحصل عليها من معادلات الأكواد المشابهة وقد وجد أن السبب في هذا يعزي إلي أن معادلة الكود

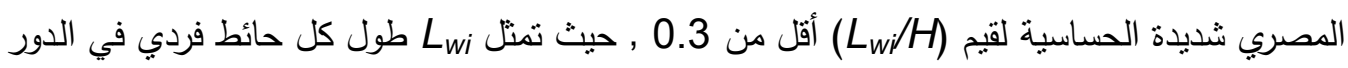

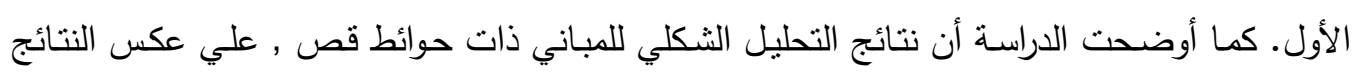

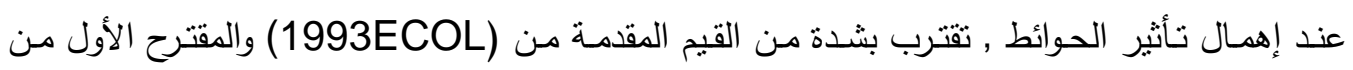
.(2003 ECOL) 